\title{
Importance of Communication in Succession Planning-A Critical Analysis of an Australian City Council
}

\author{
Prashant Singh* and Pushpa Kataria \\ Department of Organisational Behaviour and Human Resource Management, Doon \\ Business School, Dehradun, India
}

Article Type: Article

Article Citation: Prashant Singh and Pushpa Kataria, Importance of Communication in Succession Planning - A Critical Analysis of an Australian City Council, ISBR Management Journal. 2021; 6(01), 34-41. Dol: 10.52184/isbrmj.v6i1.104

Received date: March 20, 2021

Accepted date: April 25, 2021

*Author for correspondence: Prashant Singh $\nabla$ prashant. singhuq@gmail.com P Department of Organisational Behaviour and Human Resource Management, Doon Business School, Dehradun, India

\begin{abstract}
Australia's demographics are going through structural and cultural impediments, and massive changes are starting to occur in the following five years. The baby boomers' generation is in the process of retiring. The major task which consumes most of the time was to extract knowledge from the baby boomers. Moreover, it involves identifying and evaluating knowledge from critical employees and will leave the establishment sooner. Succession planning mostly involves employees, which are about to depart the organization in the short term, and new skilled employees will engage in the function. Effective succession planning requires affirmative responses regarding the department's organizational culture, functionality, goals and objectives, and relationship with the stakeholders and vision. To deliver high-quality succession planning, it is indispensable to deliver a robust SuccessorIncumbent relationship, mutual reliance, open and sincere communication. Therefore, this paper emphasizes the strategic plan for succession planning and explains how critical it is to have clear, trustable, and authentic communication between the successor and the Incumbent.
\end{abstract}

Keywords: Baby Boomers, Succession Planning, SuccessorIncumbent Relationship, Communication

\section{Introduction}

During the past decade, numerous articles have been published that warn of an imminent human capital crisis initiated by the potential retirement of millions of experienced workers at or about the same time at Brisbane City Council (BCC). The council has described "the loss of experienced workers could cause untoward effects on productivity and economic development." The major concern at BCC is the aging workforce for baby boomers and will deliver a considerable impact on the council's work. Moreover, there is a considerable gap between the older workforce in the younger pool. It gets things more complicated as the younger men have different ways of supporting life and aspiration. Hence, it is vital to 
extract the older people's data, who are leaving the workforce and communicating it to the younger generation for smooth operation.

Therefore, changing demographics has a substantial impact on the system's functioning. Furthermore, Succession plans require making up strategies for critical parts and build knowledge management discussion in parliamentary procedure to extract vital knowledge and transmit it to the concerned individual. Active listening plays a crucial function that facilitates to development of a program for the transfer of knowledge. Hence, communication takes on an essential function in knowledge transfer, which determines succession planning success. Leadership plays a major role in succession planning. Whether the organization really understand the changing dynamics of business is important? (Vincent, 2017). Furthermore, the lack of succession planning contributes to a negative view on shareholder wealth which may reduce the price of shares and impact the brand image of the company (Farah \& Li, 2021). Thus, this research essay emphasizes the importance of communication in succession planning and analyses the benefits for smooth conversion, and explains the consequence of miscommunication.

\section{Context}

Brisbane City Council is the largest local government in the Asia-Pacific region. With a permanent workforce of more than 7,000, Council employees deliver core local government services, including roads and infrastructure, passenger vehicle and ferry services, environmental security, and local parks, as well as neighborhood planning. Australia's demographics are going through structural and cultural impediments, and massive changes are starting to occur in the following five years. At Brisbane City Council (BCC), the bulk of the workforce is above 45 age, and many are likely within the age group 65-75 years. As a result, the system has to attain a workforce with the right capability for future job needs. The baby boomers' generation is in the process of retiring. They are taking with them 30-40+ years of knowledge, experience, working relationships, and information. Thus, it is important to get that knowledge before they walk out of the doorway. In the future, it helps to meet staffing requirements and also focus on both the short and long-term needs of the organization.

During the association with BCC, the major task which consumes most of the time was to extract knowledge from the baby boomers. Moreover, it involves identifying and evaluating knowledge from critical employees and will leave the establishment sooner. Since most of the employees are above 60 years, it was very significant to deliver excellent interpersonal communication and establish knowledge. Those details have to be looked up with the prospects who will supplant the existing candidate. In the whole process, the function of communication plays a significant part (Stewart, 2016).

Moreover, it depends upon the role; knowledge-sharing activities get formed, which help the younger generation to have a competitive advantage. It facilitates to have the organization's smooth functioning and prevents to have an excessive loss from the pile of employees who have a piece of substantial knowledge and are about to leave. Employees share work-connected experience, expertise, networks, share their work context, and 
technical skills through informal and formal interaction. Still, it is becoming hard to elicit some of the implicit knowledge: specific accomplishments, creativity, and accumulated experience that reside mostly with the person (Rothwell, 2010). On the reverse, the explicit knowledge can be extracted through the previous record, files, databases, and technical systems. The so-called tacit knowledge depends on the employee work profile and alters from person to person (Stewart, 2016). Lastly, the younger generation is more techsavvy, so the emphasis has been made to partake some of the tacit knowledge through Information Technology (IT) infrastructure, raising the individual's reach beyond formal communication.

\section{Literature Review}

Succession planning mostly involves employees, which are about to depart the organization in the short term, and new skilled employees will engage in the function. In such a scenario, knowledge transfer is a vital factor, and through proper communication, the firm can stock human and relational capital essential for the enterprise (Cadieux, Lorrain, \& Hugron, 2002). Lack of effective communication may discourage knowledge sharing, thereby, affects gathering vital data.

Successful succession planning involves trust and secure communication, and these traits help to ride the organization's success. People experience different personalities, so communication had to be done with different techniques based on affairs (Crumpacker \& Crumpacker, 2007). Such a method will help to plan positive succession planning. The main gist of succession planning is to develop a sense of positive communication, and more importantly, consistency should be present in the communication (Griffith, 2012; Larsson, 2020).

In designing succession planning, the organization needs to have a clear objective and goals. Moreover, unique to the respective department template has to establish, and emphasis should be afforded to demonstrate faith and kinship. It will help draw out the knowledge and some of the historical knowledge (Dyck, Mauws, Starke, \& Mischke, 2002). Succession planning is mainly a transition between the two distinct kinds of employees, and communication coupled with confidence and commitment facilitates the conversion. Effective succession planning requires affirmative responses regarding the department's organizational culture, functionality, goals, and objectives, relationship with the stakeholders, and vision (Durst \& Aggestam, 2016). These activities involve a high emphasis on different communication patterns.

Succession mainly implies a strategy to bring the right candidate for the vital role, demonstrating the substantive changes that will happen in the organization. The loss of knowledge is likely to occur, and approaches have to be taken to extract the knowledge and utilize it properly through various communication channels (Durst \& Aggestam, 2016). The departure of valuable employees will impinge on the organizational success so, the transfer of critical knowledge becomes important as much tacit knowledge is stored in the people's psyche (Ismail \& Mahfodz, 2009). 
It emphasizes the importance of coordination between the employees. IT-supported repositories help extract critical knowledge to the desired person (Durst \& Aggestam, 2016). There should be mutual positive feelings between the incumbent and the successor. It will establish trust between them, or otherwise, the successor might reject the incumbent's essential knowledge. Such a step would help when the successor has to undergo the organization's transition phase (Kim \& Lee, 2006).

To deliver excellent succession planning, the organization must communicate the ups and down to the incumbent before the conversion. The incumbent should fully realize the responsibilities and dangers of succession plans (Miles, Marshall, Rolfe, \& Noonan, 2006). The main stakeholders and the functional department head should design realistic responsibilities that could quickly draw out the knowledge and help the successor take up a new character (Griffith, 2012).

Communication issues occur between the incumbent and the successor during the process. Hence, it is critical to delivering clear communication between the two parties, minimizing potential loss opportunities (Miles et al., 2006). Unclear communication leads to a lack of trust, which gives the impression to the successor that the incumbent is hiding the information. Moreover, sometimes, some negative experiences in the organization lack trust, which may ruin the transition's effective plans (Perrenoud \& Sullivan, 2017).

Few companies maintain a high tier of communication during the succession planning and the transition procedure. They emphasize the vitality of communication, and so the company communicates the succession plans to various stakeholders such as clients, staff, and service providers. It indicates that the firm thinks communication equally crucial as cash flow for success (Rhodes \& Brundrett, 2009).

In the lodge, there are multiple communication channels between the groups frequently to experience a successful succession. Hence, maintaining a high degree of communication brings effectiveness during the transition, and the stakeholders are aware of the changes going to materialize in the system (Perrenoud \& Sullivan, 2017). To have better organizational performance effective succession plan coupled with precise communication, go a long path.

In another article, few authors provide a different perspective in the field of succession planning. They argued that the poor communication between the heir and the incumbent leads to defeat in the successor and might even push to look for fresh opportunities (Rothwell, 2010). Such a step mostly occurs when the successor gets confused about the purpose, and the inadequate method of communication does not supply the system's overall plan. A successor could not speculate about the succession plan and get lost. Engaging properly with the groups may keep off any future turmoil (Sánchez \& MorrisonSaunders, 2011).

Succession planning happening in the organization is to facilitate the baton in a relay race. It involves having harmonious cooperation, which helps to pass the baton, and also trust is equally important. Furthermore, the author also emphasizes having clear visual and oral communication for an effective handoff (Schiuma, Durst, \& Wilhelm, 2012). Effective communication and excellent interpersonal relations between the incumbent and the successor enhance the likeliness to gain trust between them and increase effective succession prospects (Sharma \& Sengupta, 2017). 
For strategic succession, both the incumbent and the successor roles are critical, and if there is a lack of confidence, inadequate communication, conflict over the strategies and procedure, or unable to understand the shared vision of the establishment will derail the chances of effective succession (Sharma, Chrisman, \& Chua, 2003).

Both the incumbent and the successor will lament the lack of confidence and communication between them, which hamper the succession procedure. Hence, it is important to have a mutual understanding of the goals and maintain some good interpersonal relations (Whelan \& Carcary, 2011). The organization should focus on healthier and more transparent communication while implementing the succession plan. It will reduce the interpersonal resistance between individuals and positively affect organizational resistance (Perrenoud \& Sullivan, 2017; Lenz \& Glückler, 2021). The presence of quality of interpersonal relationships among the prominent persons in the succession process will positively impact the business environment. The more problems that occur in the relationship between the main individuals, are more likely to have a hostile succession (Stewart, 2016).

\section{Discussion}

With acknowledgment to the literature, it is clear that to sustain a smooth transition process in succession, it is important to deliver a clean and candid sort of communication. At the Brisbane City Council (BCC), it has been noted that there is a lack of succession and transition provision. It runs out to acknowledge the vitality of the workforce's shifting nature and has not realized the organization's strategic ends.

To deliver high-quality succession planning, it is indispensable to provide a robust Successor-Incumbent relationship, mutual reliance, open and sincere communication. Nevertheless, this was the primary concern at BCC while conducting one-to-one sessions with the Incumbent. An ineffective relationship between two groups and unwillingness to immediately explain the differences in openness regarding some of the responsibilities and expectations often lead to withholding vital information and creating stress.

Furthermore, by observation, it has likewise been found that the Department Managers has not even finalized the successor, and the preparation has not yet happened with the Incumbent. It leads to a certain amount of dissatisfaction and lack of trust in the Incumbent mind.

The decision has not been well communicated to other stakeholders. The role of the departing Incumbent is not yet appropriately defined. There is also a lack of a strategic plan that needs to develop from having an effective succession. Likewise, some of the successors do not possess the appropriate skills to replace the Incumbent. Moreover, there is a lack of clarity in a post - succession roles, and it is the responsibility of the departing Incumbent to have clear communication with the successor.

Few events have placed where the Incumbent has almost lost the pursuit of the organization's vision and does not express an interest in organizational interest. In such a scenario, explicit knowledge is provided through documents and forms. Still, on the other hand, much implicit knowledge and historical knowledge would not document just because 
the Incumbent was interested in withholding the information. These circumstances lead towards an ineffective succession and affect the post-succession business outcome.

Lack of faith between the Incumbent and Successor, inadequate and unclear communication, disinterested in the organization goals, behavioral mismatch among individuals due to differences in generations. In such a situation, Incumbent raised responsibility and ownership, making it cumbersome for Successor to have clarity on multiple crucial issues.

\section{Conclusion}

In succession planning, strong communication and interpersonal relations play a significant role in strategic succession success. The evidence suggests that determination, mutual trust, desirability, believes in the organization's vision, and emotional intelligence have a substantial impact on the succession. Such actions establish the organization strong and organize the firm to substantiate in the rapidly shifting business environment. Moreover, the literature clearly illustrates the importance of the Incumbent role in the succession-planning process. Incumbent willingness and trust facilitate the successor to hold the position later, and the establishment could get an advantage with the historical knowledge of the Incumbent. To maintain a successful long-term impact, organizational factors such as consistency in communication, understanding of each other behavioral patterns, and cultural battles have brought into thoughtfulness. The success of succession planning depends upon the top management as they are the one who designs the scheme, and the responsibilities and expectation should be communicated across the department, especially successor and incumbent. Both the successor and the incumbent are sensitive to the inconsistencies that happen in the succession process.

At BCC, based on the experience, it is clear that authentic and transparent communication holds a significant place in the workplace in such a technological era. To determine succession planning success, it is crucial to have clear and precise communication. Furthermore, for succession satisfaction and effectiveness, specific components like succession sequence, technique, timing, behavioral pattern, and communication with high emotional intelligence matter to succession success. Succession planning is needed not just in the best economic condition but too in the most uncompromising position. In Brisbane City Council (BCC), they should strategically plan for the future requirements and changing trends of the economy.

Moreover, BCC should plan for its employees, as trusting only the external candidates for talent is merely a suboptimal strategy. Pushing aside the importance of companyculture-specific experiences and wisdom could spread disengagement among the surviving employees. Therefore, strategic planning for succession planning has to do with consulting among various stakeholders and, most importantly, clear, trustable, and authentic communication while conducting a succession plan. 


\section{Acknowledgments}

We thank the Brisbane City Council (BCC) and the University of Queensland (UQ) to conduct the research. We are also grateful to BCC staff members who provided the opportunity to interact with their team-members; without them, it would be difficult to have an analysis.

\section{References}

Cadieux, L., Lorrain, J., \& Hugron, P. (2002). Succession in women-owned family businesses: A case study. Family Business Review, 15(1), 17-30. doi: 10.1111/j.1741-6248.2002.00017.x

Crumpacker, M., \& Crumpacker, J. M. (2007). Succession planning and generational stereotypes: Should HR consider age-based values and attitudes a relevant factor or a passing fad? Public Personnel Management, 36(4), 349-369. doi: 10.1177/009102600703600405

Durst, S., \& Aggestam, L. (2016). IGI Global, Hershey, PA, Using IT-supported knowledge repositories for succession planning in SMEs: How to deal with knowledge loss? Handbook of Research on Human Resources Strategies for the New Millennial Workforce, 393-406.

Dyck, B., Mauws, M., Starke, F. A., \& Mischke, G. A. (2002). Passing the baton: The importance of sequence, timing, technique and communication in executive succession. Journal of business venturing, 17(2), 143-162. doi: 10.1016/S0883-9026(00)00056-2

Griffith, M. B. (2012). Effective succession planning in nursing: A review of the literature. Journal of Nursing Management, 20(7), 900-911. doi: 10.1111/j.1365-2834.2012.01418.x.

Ismail, N., \& Mahfodz, A. N. (2009). Succession planning in family firms and its implication on business performance. Journal of Asia Entrepreneurship and Sustainability, 5(3), 86-107.

Kim, S., \& Lee, H. (2006). The impact of organizational context and information technology on employee knowledge sharing capabilities. Public Administration Review, 66(3), 370-385. doi: $10.1111 / \mathrm{j} .1540 .6210 .2006 .00595 . \mathrm{x}$

Farah, P., \& Li, H. (2021). The Effects of CEO Succession Planning on Shareholder Wealth. International Journal of the Economics of Business, 1-16. doi:10.1080/13571516.2021.1945856

Larsson, T. (2020). Royal Succession and the Politics of Religious Purification in Contemporary Thailand. Journal of Contemporary Asia, 51(4), 1-21. doi:10.1080/00472336.2020.1849775

Lenz, R., \& Glückler, J. (2021). Same same but different: regional coherence between institutions and policies in family firm succession. European Planning Studies, 29(3), 536-555. doi:10.1080/ 09654313.2020.1757041

Miles, R. L., Marshall, C., Rolfe, J., \& Noonan, S. (2006). The attraction and retention of professionals to regional areas. Australasian Journal of Regional Studies, 12(2), 129.

Perrenoud, A. J., \& Sullivan, K. T. (2017). Analysis of Executive Succession Planning in 12 Construction Companies. International Journal of Construction Education and Research, 13(1), 64-80. doi: 10.1080/15578771.2016.1143892

Rhodes, C., \& Brundrett, M. (2009). Growing the leadership talent pool: Perceptions of heads, middle leaders and classroom teachers about professional development and leadership succession planning within their own schools. Professional Development in Education, 35(3), 381-398. doi: 10.1080/19415250902987122

Rothwell, W. J. (2010). Effective succession planning: Ensuring leadership continuity and building talent from within. AMACOM, A Division of American Management Association: New York, NY. 
Sánchez, L. E., \& Morrison-Saunders, A. (2011). Learning about knowledge management for improving environmental impact assessment in a government agency: The Western Australian experience. Journal of environmental management, 92(9), 2260-2271. doi: 10.1016/j. jenvman.2011.04.010

Schiuma, G., Durst, S., \& Wilhelm, S. (2012). Knowledge management and succession planning in SMEs. Journal of Knowledge Management, 16(4), 637-649. doi: 10.1108/13673271211246194

Sharma, A., \& Sengupta, T. (2017). Perspective on succession planning in multiple MNCs: Interview with Aparna Sharma. Human Resource Development International, 21(4), 382-390. doi: $10.1080 / 13678868.2017 .1306770$

Sharma, P., Chrisman, J. J., \& Chua, J. H. (2003). Succession planning as planned behavior: Some empirical results. Family Business Review, 16(1), 1-15. doi: 10.1111/j.1741-6248.2003.00001.x

Stewart, D. A. (2016). Human Capital Management-The Need for Succession Planning. Association of Municipal. Managers, 1-23.

Whelan, E., \& Carcary, M. (2011). Integrating talent and knowledge management: where are the benefits? Journal of Knowledge Management, 15(4), 675-687. doi: 10.2139/ssrn.1694455

Vincent, W. S. (2017). Succession planning for the family-owned business. GPSolo, 34(5), 34-37. Retrieved July 11, 2021, from https://www.jstor.org/stable/26586485 